Research:

\title{
THE ROLES OF SYARIAH MICRO FINANCE INSTITUTION (LKMS) IN ELIMINATING THE POVERTY IN INDONESIA (CASE STUDY OF BAITUL MAAL WAT TAMWIL)
}

\author{
By: \\ Syarief Gerald Prasetya \\ Lecturer at STIE Binaniaga Bogor
}

\begin{abstract}
In accordance with BPS data mentioning that the total of poor people in Indonesia in September 2014 had reached 27.73 (10.96\%), this total was still quite big eventhough it had been decreasing from time to time eversince. It explains that there are still many people leaving under poverty limitation. The main reason is that they do not have any sufficient financial capital to do their business since most of poor people are UMKM (Small and Middle Business class) people. Therefore BMT (Baitul Maal Wat Tamwil) has appeared to help grass-root people obviously as BMT roles has been able to increase their productivity accordingly. Relating to the total of poor people which had been reducing since 2009 up to September 2014 except in September 2013 it had increased due to the increasing price of the fundamental goods needed by the people refers to the increasing price of BBM (fuel) in June 2013. As a matter of fact, it is getting along with the increasing of BMT Institutions in Indonesia so that the existency of BMT has been the most important roles in elimination of the poverty in Indonesia.
\end{abstract}

Keywords: baitul maal wat tamwil, poverty, micro finance institution.

\section{INTRODUCTION}

\section{A. Background of the Problems}

The Poverty has been a crucial matter in Indonesia since the efforts of the government has not been yet very maximized due to the fact that there is still quite big percentage of poverty in Indonesia. BPS (Statistical Center Bureau) in September 2013 identified 28.55 milion poor people in Indonesia or $11.47 \%$. Nevertheless, the quality of Human Resources (SDM) in Indonesia has shown potential efforts creating jobs opportunities. But they have encountered the financial capital problem, it is very difficult for them to obtain the financial capital needed due to very high interests offered by finance institutions reflecting to the poor people who should have to cancel their willingness to start their own business because they are afraid to be failed and are not able to pay their debts due to a huge interest.

Eliminating poverty, the government has been applying some best solutions either national or international scales. Refers to the international scale, Indonesia has been a part of the establishment of Islamic Development Bank (IDB), and members of IDB are Islamic Countries which have been joining the Islamic Conference Organization (OKI). IDB is a finance institution promoting Islamic system refers to 'syariah' system which is non interest and non fee for overdue, but according to the mark-up guideline it is a measurement to define a profit. IDB is not a commercial banking or finance instution or organization, or social organization such as BAZIS (Badan Amil Zakat, Infak dan Shadakah- an administration that is managing people contribution, donation, etc)

BMT is a finance and business institution applying Syariah principle which is the same with cooperative unit or LSM (Community Self-supporting basis). Baitul Mal wat Tamwil was a pioneer in establishing Bank Syariah in 1992. BMT has been serving people who have met some difficulties dealing with the bank. The development of BMT has been quite significant due to the support of Yayasan Inkubasi Bisnis Usaha Kecil (YINBUK = The Foundation of Small Business Unit Incubation) promoted by MUI (Indonesia Moslem Leaders). 
BMT is different with Bank Syariah relating to its support and assistance. Bank Syariah is relied on the government regulation under the Department of Finance or the regulation of Bank of Indonesia (BI), but BMT which is a cooperative legal institution is under supervision of The Ministry of Cooperative and Small business units and Medium business units. Therefore, the establishment and superivision of BMT is under the Ministry of Cooperative and Small Business Units and Middle Business Units refers to the regulation of the Minister of Cooperative and Small Business and Middle Business units No. 91/Kep/M.KUKM/IX/2004 regarding The Operational Guideline about Business Activities of Syariah Finance Cooperative Services.

BMT development, nowadays BMT executors have joined with some associations such as Absindo (Indonesia BMT Association), BMT organization, BMT Syariah Cooperative Headquarter (Inkopsyah), Syariah Baitul Tanwil Muhammadiyah Finance Cooperative headquarter,etc. "Those associations have been educating and developing BMT quite significant (Setyo; Republika Online). Based on the aforementioned background, a study about "The Roles of Syariah Finance Institution in eliminating the Poverty (Case study at Baitul Maal Wat Tamwil in Indonesia) has to be performed.

\section{B. Problems Formulation}

The problems offered in this study has been formulated as follows: Based on the observation result, the following formulation of the problems are as follows:

1. How can BMT develop the members financial sector?

2. How can BMT develop the members education in a real sector?

3. How can BMT develop the members religious?

4. How can BMT eliminate the poverty in Indonesia?

\section{Objective of the study}

Refering to the aforementioned problems, this study aims to:

1. Recognize the roles of BMT in developing the financial sector for their member

2. Recognize the roles of BMT in developing a real sector for their member.

3. Recognize the roles of BMT in developing the religion of their member.

4. Recognize the roles of BMT in eliminating the poverty in Indonesia.

\section{Methodology of the Research}

1. Data Collection Method

This study has applied a secondary data which is using the information data related to the development of infrastructure of Syariah finance institutions in Indonesia either obtained from the Ministry of Finance of the Republic of Indonesia or other resources such as Research journals, books or magazines from the Bureau of Statistical Center.

2. Data Analysis Method

This study has applied a data analysis applying a descriptive analysis method which is an analysis describing or explaining a certain object. This study will describe about the development of micro syariah finance institution of "Baitul Maal Wat Tamwil" and the poverty data in Indonesia.

\section{LIBRARY REVIEW}

\section{A. Baitul Maal Wat Tamwil (BMT)}

Lubis (1995) defined baitul maal means literally a house of wealth or riches or property. Nevertheless, baitu maal can be determined as a Treasury House (public or government). Referring to fikih terminology, baitul maal is an institution or administration which is in charge of organizing the government wealth / properties especially in finance which is government revenue and management, eventhough it is relating to the government spending. But baitul tamwil is a private treasury house being managed by a certain institution. According to Azis (2004) determined BMT is a micro finance institution being operated based on profit sharing 
principles (syari'ah), is developing micro business units and small ones to increase people dignity and helping the poor people.

BMT has two conceptual functions: Baitul Tamwil (Bait $=$ house, at Tamwil = Wealth evolvement) is performing the activities to evolve a productive business unit as well as an investment in relation with the improvement of economical quality of micro and small business especially to make people being interested in saving money and to provide the economical funding. Baitul Maal (Bait = house, Maal = wealth) is receiving zakat fund, infak and shadaqah in order to execute the distribution of the money appropriately. So that the main activity of BTM is collecting some money and redistributing it to the member which is in accordance with the profit sharing principles or marking up / margin based on BMT syariah.

The legality of BMT is under a cooperative unit, so that BMT should have to follow the Acts no. 25 year of 1992 regarding the Cooperation units refers to the Government Regulations No. 9 year of 1995 regarding the Execution of lending and saving money in a cooperation unit, refers to The Decree of the Minister no. 91 year of 2004 regarding the Cooperation Unit of Syari'ah finance services. Nevertheless the operational system of BMT is almost the same with Syari'ah Banks principles. Then, BMT products are similar with Bank Syariah products that should have to respect the banking regulation No. 7 year of 1992 regarding the implementation of the regulation which is The government regulation no. 71 year 1992 regarding BPR and PP (government regulation) no. 72 year of 1992 that has regulated bank principles which is having profit sharing principles. Acts no. 7 year 1992 was replaced by Acts no. 10 year 1998 .

BMT mission and vision is directing to the efforts of BMT as an institution that is able to improve the quality of religious service of the members (religious service in a broad meaning) which is Allah SWT representative to make the life of the member better in particular and the society in general. The point is that BMT will be creating professional institutions which are being able to enrich the quality of religious service. BMT mission is constructing and developing the economical structure and society prosperity as well as fairness based on syari'ah principles and blessed by Allah SWT. Based on the aforementioned understanding, it explains that BMT is not only looking for a profit and collecting some money from the rich people, but also is having an orientation to a fair profit distribution which is in accordance with the principles of economic Islam.

The other important operational BMT is distributing the financing needed. BMT financing distribution can be classified based on the purpose of financial utilization, as follows;

1. $\quad$ Trading

Trading or Selling and Buying is a contract being performed between a seller and a buyer to deal with trading transaction refers to goods and price. The implementation of this kind of trading transaction in BMT refers to the products of 'murabahah', 'salam' and 'istishna' financing.

2. Profit Sharing.

The implementation of profit sharing in the transaction of Syariah Finance Institutions (LKS) is well-known in the society because the function of profit sharing is the replacement of bank interest. Practically BMT can use this contract either in saving or lending the money and the implementation of profit sharing is based on savings, and financing refers to 'Mudharabah and Musyarakah' financing.

3. Renting

Renting is an agreement about renting an object either a product or a service that has given a profit for the users and they should have to pay for it. BMT has applied this kind of transcaction relating to finance distribution refers to'ijarah' financing and 'ijarah muntahia bit tamlik' financing.

4. Services Principles

This kind of financing transaction is a service based on 'ta'awum or tabarru'i' principles which is helping people in a positive way refers to al wakalah, kafalah / guarantee, al hawalah/take over of the loan, and ar rahn (pawning).

5. Social Loan.

BMT Social Loan is recognized as 'qardh' financing which is providing a loan without any interest but the people who get the loan should have to pay it within a certain period agreed by both parties. 


\section{B. Poverty}

A poverty is a low standard of living of a group of the people who do not have enough property or money comparing with other people who have had a sufficient standard of living. This low standard of living has been reflecting to the people health, moral and dignity who are classified poor people.

Furthermore, poverty is a condition where a person, family, group of people, nation or state that can do nothing and this situation has made them vulnerable to social problems. Chamber said that poverty is an integrated concept having five dimensions; poverty, powerless, vulnerable state of emergency, dependency and isolation either sociologically or geographically. Living in a poverty does not mean lack of money and low income but it is relating to the following matters; health, low education, laws unfairness, crimes vulnerability, powerless against the state or even for their own live.

\section{DESCRIPTION}

\section{A. Development of Baitul Maal Wat Tamwil in Indonesia.}

In 2005 an association was established and it has aimed to develop syariah microfinance in relation with UMKM which is the Association of Baitul Maal Wat Tamwil in Indonesia (Absindo) that has been about $3.000-4.000$ BMT units in Indonesia. This development has happened due to the effort of micro scale of BMT being closed to the middle and lower class of the community. Having a certain amount of finance capital and some people who would like to perform syariah principles, it is sufficient to establish a BMT even though in a small isolated village.

Absindo has been supporting lots of BMT in Indonesia either a new member or existing ones because it has provided full support in developing a micro syariah finance institution, and it has been making business relationship either national or international, developing the roles of micro syariah finance institutions so that BMTs members have been able to improve their finance sector and real sector. Table 1 is a description about micro syariah finance institutions today and in the future based on Absindo.

Table 1.

KMS BMT today and in the future

\begin{tabular}{|l|r|r|r|}
\hline \multirow{2}{*}{ Description } & \multicolumn{3}{c|}{ Condition } \\
\cline { 2 - 4 } & \multicolumn{1}{|c|}{ now } & next 3 years & next 10 years \\
\hline Profit & million/month & million/month & billion/month \\
\hline Asset $10-250$ juta & Rp. 1,25-5M & Rp 10-100 M \\
\hline SOP & not orderly & orderly & orderly \\
\hline Management & closed & open & open \\
\hline $\begin{array}{l}\text { Additional founders } \\
\text { budget }\end{array}$ & closed & open & open \\
\hline Ruhiyah strengthening & not yet running & running well & running well \\
\hline Total of the member & $100-500$ & $5000-8000$ & $10000-100000$ \\
\hline
\end{tabular}

Resources : Absindo, 2014

Based on the aforementioned table it explains that Absindo has been supporting very well and working on the prospect of BMT either just joining the group or for the next 10 years. it has triggered BMT to work harder and harder and to modify the patern of financing sector by increasing the profit and assets of BMT cooperation unit, as well as real sector by providing lots of related trainings based on the Standard Operating Procedure (SOP), the management is more open and religious refers to ruhiyah strengthening by applying zakat/tithe, infak and sodaqoh / donation.

According to Inkopsyah, BMT has 432 members which is from Nanggro Aceh Darussalam up to West Papua, and the total assets in 2014 amounting to 306 billion which is an increasing of 77 billions or $33.6 \%$ comparing to the total assets in 2013 which is 229 in Eliminating The Poverty in Indonesia (Case Study of Baitul Maal Wat Tamwil) 
billions. The following table has been explaining about the total asset and profit based on the financial report of Inkopsyah BMT:

Table 2.

Total assets and profit Inkopsyah BMT

\begin{tabular}{|c|r|r|}
\hline Year & \multicolumn{1}{|c|}{ Total Assets } & \multicolumn{1}{c|}{ Profit } \\
\hline Des 2014 & $305,714,115,882.15$ & $3,170,995,769.96$ \\
\hline Des 2013 & $229,179,164,496.00$ & $2,094,688,165.00$ \\
\hline Juni 2012 & $151,781,028,875.46$ & $994,082,062.08$ \\
\hline Juni 2011 & $99.032 .285 .355,01$ & $1.105 .699 .974,09$ \\
\hline
\end{tabular}

Resources: Inkopsyah BMT: 2015

Based on the data aforementioned, it explains that BMT's assets had been increasing since 2011 to 2014, it means that BMT is qualified to manage the assets better and it has sufficient assets to run the operational activities accordingly. The profit had been increasing accordingly simce 2011 up to 2014 except in 2012 it had decreased due to small total of Inkopsyah members or lots of new members were just trying to start up their business. In 2015 was the best quality of BMT. The quality of BMT means (1) good or bad of the content / quality. (2) degree or stage of intelligence, skills, etc and or quality. So that the quality achievements will be getting along with the endurance of BMT, performance of BMT and BMT networking which is better and stronger networking that can increase the volume of business units obviously, but a big volume of business does not mean good quality.

The cooperation unit of syariah finance service (KJKS) and the cooperation unit of Baitul Mal Wa Tamwil (KBMT) are obliged to be a partner of financial product management based on syariah refers to wakaf and zakat, infak and shadaqah. When wakaf and zakat had been managed by amil or zakat organization which is KJKS / KBMT having the competency to develop micro business, then big advantages would be happened because it has been financing the productive ones. Potential financing refers to zakat, infaq, shadaqah and wakaf (ZISWAF) in Indonesia has reached the amount of Rp 217 trillion (Baznas, 2012) and wakaf itself Rp 120 trillion (BWI, 2014). Considering such a big amount, then collecting and using zakat and wakaf have been a strategic potential financing in relation to the development of micro or small business units especially for poor people to be able to survive economically due to the presence of BMT.

\section{B. Poverty in Indonesia}

According to the data of BPS (Statistic Center Bureau) up to September 2014 indicated that the number of poor people in Indonesia was $27.73(10,96 \%)$ which is it had reduced 0.55 million comparing with the total of poor people in March 2014. But comparing to a year before the total of poor people had reduced 0.82 million people which was 28.55 millions $(11.47 \%)$ in September 2013. Based on the location of their resident, for the period of March - September 2014 the total of poor people in the cities had decreased 0.15 million people (10.51 million in March 2014 to 10.36 million in September 2014), but in the villages it had decreased 0.40 million people (17.77 million in March 2014 to 17.37 million in September 2014). Nevertheless, comparing to a year before refers to September 2013 - March 2014 the total of poor people in the cities had decreased 0.17 million (10.68 million in September 2013 to 10.51 million people in March 2014), but in the villages it had decreased 0.15 million people (17.92 million people in September 2013 to 17.77 million in March 2014). Moreover, the percentage of poor people in the cities and the villages had not changed significantly for the period of $2013-2014$, in September 2013, 62.66\% of poor people lived in the villages, in March 2014 it was $62.88 \%$ and in September 2014 it was $62.64 \%$. In order to understand clearly the condition of poverty in Indonesia in 2009 to September 2014, table 3 has been describing itt. 
Table 3

Total and percentage of poor people in Indonesia Based on the district in 2009 - 2014

\begin{tabular}{|c|r|r|r|r|r|r|}
\hline \multirow{2}{*}{ Year } & \multicolumn{3}{|c|}{$\begin{array}{c}\text { Total of poor people } \\
\text { (in million) }\end{array}$} & \multicolumn{3}{c|}{$\begin{array}{c}\text { Percentage of poor people } \\
\text { (in \%) }\end{array}$} \\
\cline { 2 - 7 } & City & \multicolumn{1}{|c|}{ Village } & City+village & \multicolumn{1}{c|}{ City } & \multicolumn{1}{c|}{ Village } & City+village \\
\hline 2009 & 11,91 & 20,62 & 32,53 & 10,72 & 17,35 & 14,15 \\
\hline 2010 & 11,1 & 19,93 & 31,02 & 9,87 & 16,56 & 13,33 \\
\hline March 2011 & 11,05 & 18,97 & 30,02 & 9,23 & 15,72 & 12,49 \\
\hline $\begin{array}{c}\text { September } \\
2011\end{array}$ & 10,95 & 18,94 & 29,89 & 9,09 & 15.59 & 12,36 \\
\hline March 2012 & 10,65 & 18,49 & 29,13 & 8,78 & 15,12 & 11,96 \\
\hline $\begin{array}{c}\text { September } \\
2012\end{array}$ & 10,51 & 18,09 & 28,59 & 8,60 & 14,70 & 11,66 \\
\hline March 2013 & 10,33 & 17,74 & 28,07 & 8,39 & 14,32 & 11,37 \\
\hline $\begin{array}{c}\text { September } \\
2013\end{array}$ & 10,63 & 17,92 & 28,55 & 8,52 & 14,42 & 11,47 \\
\hline March 2014 & 10,51 & 17,77 & 28,28 & 8,34 & 14,17 & 11,25 \\
\hline $\begin{array}{c}\text { September } \\
2014\end{array}$ & 10,36 & 17,37 & 27,73 & 8,16 & 13,76 & 10,96 \\
\hline
\end{tabular}

Source : Processed data of the National Economic Social Survey

In general, in 2009 to September 2014 the poverty in Indonesia had decreased except in September 2013. In September 2013 the total and percentage of poor people had increased comparing to the one in March 2013 due to the increasing price of the main fundamental goods refered to the increasing price of petrol in June 2013. Furthermore in September 2013 to September 2014 the total and percentage of poor people in the cities and villages had been decreasing accordingly.

Most of poor people in Indonesia are a group of people who have been doing small, micro and middle business activities (UMKM), so that developing UMKM is obliged to be done to reduce the poor people in Indonesia. According to the Acts No. 20 year 2008 regarding UMKM, a micro business unit is a productive business belongs to the person individually and/ or and individual business unit that has been covering the criteria of micro business regulated in this Acts and the maximum total asset is 50 millions rupiah and sales total is 300 millions maximum. A small business unit is a private productive economic business being performed individually or a business unit which is not a start-up enterprise or a branch office or a part of medium or big business unit either directly or indirectly having the total assets more than Rp 50 million up to 500 millions and the sales total of more than Rp 300 million up to Rp3.5 billions. Middle business unit is a private productive business unit performed individually or by an enterprise that is not the branch of a certain company and it has the total assets of more than $\mathrm{Rp} 500$ million to $\mathrm{Rp} 10$ billion and sales total Rp 2.5 billions to $\mathrm{Rp} 5$ billions. According to Bank of Indonesia; a business belongs to an individu or family using a simple technology and a mass product, low education and skills, a few is not registered legally and or is not having a legal entity, does not pay any tax. Furthermore this regulation has been changed by PP (Government Regulation) 46 year of 2013.

In connection with the aforementioned description, UMKM needs to be improved and developed to reduce the jobless people so that it is reducing the total of poor people in Indonesia. The existency of finance institution such as Banks, syariah finance institution, cooperation unit, and the one that has been developing which is Baitul Maal Wat Tamwil has provided an easy loan facility, no enforcement, and syariah basis which is very helpful for the new business people who need financing support.

\section{BMT Roles in Improving the Financial Sector.}

BMT or baitul maal watamwil is corresponding with the House of Integrated Independent Business. Baitul mall has a function to collect and distribute some funding such 
as zakat, infaq and shadaqah (ZIS) accordingly. But, baitul tamwil is an effort to develop some productive investments which is in accordance with the quality development of small business unit by influencing them to save their money to support their economy. As a matter of fact BMT has been trying to integrate two different activities either profit or non-profit oriented within one organization. Sosial activity is a supporting one (Baitul Maal) and business activity is a main activity (Baitul Tamwil). As a social organization (Baitul Maal), BMT has a function to collect some social funds refers to zakat, infak and shadaqah or other halal resources that will be distributed to the right person (mustahiq) and non-profit oriented. As a business organization (Baitul Tamwil), BMT is an intermediary to distribute the financing which is a profit oriented.

Finance collection has been obtained through the third parties' savings(member of BMT) refers to wadiah savings and mudharabah, the distribution of the money is connected with the investment or financing, trading principles (murabahah, salam and istishna), profit sharing principles (Mudharabah and musyarakah), renting principles (ijarah and ijarah muntahia bitamlik / IMBT) and qardh financing which is in accordance with syariah principles. In this case BMT has a function as an organization that manages and develops the money of the people by having a mutual relationship between BMT management and the community which is collecting the money from the people and then distributing it back to them who are running a productive business sector and need financing support refers to profit receivable.

Operational principles of baitul mall wa tamwil is a developing agent, professionalism and Ilamiyah principles. BMT has two roles. First as an institution established based on bottom-up initiative. BMT is mobilizing the potential of economic community in order to increase members wealth. In this case, BMT is a business organization. Second, BMT is a social organization which is a bridge between agniya, shahibul maal(very rich people) and dua'fa (very poor people), a mudharib(financing user) especially in connection with the development of productive business.

As a matter of fact, there are still so many poor people who are living under the limitation of poverty. The main reason is that they do not have any financial capital support doing a business. Because, they are not easy to get a loan from the bank since they are beyond of bank requirements (non bankable). Therefore the most important role of BMT is an agent that is increasing their productivity refers to fair economics, profit sharing in relation with investment so that it could minimize a big discrepancy between the riches and the poor people who need financing support, and at the end there is not any more the riches centralized. The establishment of BMT is being one of a syariah finance institution which is a legal cooperation unit and an effort mobilizing people economy who are mayority moslems. This kind of finance institution (BMT) has helped grass-root people depending on the bad creditor with an excessive interest, because it has two kind of visions; First, baitul maal division has been managing zakat, infaq and sadaqah (ZIS) trying to develop weak people becoming more productive in their life and making use of ZIS financing which is social soft loan. Second, baitul tamwil division has been managing people savings and capital distribution based on profit sharing. It is expected to apply Islam economic system obviously. It means that the financing support provided by BMT is considered as a temporary financing support or non-permanent one, the people are educated to be able to manage such a loan in order to increase their economic condition. Having a financing support, micro community can create a financing capital accumulation, increasing a surplus and wealth of the people in general, then for the poor customers but having a business ability, BMT has been providing a financing which is qardul hasan (those customers are requested to return the amount of the loan only without any interest). Having a concept of grass-root economics development, BMT has been helping micro community to be able to fulfill their needs, they do not need to be relied on the government subsidy, but they can create a capital surplus, so that they can increase their productivity accordingly.

\section{BMT Roles in Developing Real Sector Education}

In relation with the development of micro business or informal sector, some main factors that have determined whether a productive business in a community can evolve effectively or not are working capital, proper technology, business management model and skills development related to utilizing working capital, technology, business management and 
working ethics as well as working spirits. Referring to the aforementioned factors, some important aspect relating to the development of micro business done by BMT are as follows:

1. Human Resources Management aspects such as education, training or skills can improve the people skills and competency in business.

2. Finance capital aspect refers to business capital loan support.

3. Working method aspect or business management refers to technical supports such as bookkeeping management, field training which is the way to dealing business efficiently and effectively.

4. Profit Increasing aspect.

As a matter of fact, people are dreaming to live in a good society, wealth, modern, be able to get along with all problem instead of living behind. Expected community they want is having a fair treatment and wealth refers to the Ideal of the Republic of Indonesia which is the realization of people wealth and fairness in relation with the development execution.

\section{E. BMT Roles in Religious improvement}

BMT has been a non bank syariah finance institution that has managed ZIS paid by Moslem people accordingly. Therefore, BMT is expected to be able to receive and distribute the financing properly. BMT is expected to be able to guarantee the riches to contribute ZIS and is reliable to distribute the money to moslem people accordingly. It can be determined that zakat, infaq and shodaqoh are Islam economic foundation, muamalat guideline, people economic pilar which is very special in Islam because it is not only just 'ibadah' (ibadah mahdhah such as praying and fasting) but also 'ibadah' relating to the economy, finance, and community. Besides, zakat, infaq and shodaqoh have a religious and philosophy meaning.

\section{F. BMT Roles in the Effort of Poverty Elimination.}

In compliance with BPS data, total of poor people in Indonesia reached 27.73 (10.96\%) in September 2014, this total is still quite big eventhough from time to time it is decreasing. It has indicated that there are still lots of people living under the poverty limitation. The main reason is that they do not have any finance capital support because lots of poor people in Indonesia are UMKM actors. Beginner UMKM people are usually facing a difficulty to get a loan or finance support, because they are not bankable (not in compliance with bank qualification). Therefore, BMT establishment has helped them a lot since BMT has a very crucial roles as a tool to increase their productivity refers to creating a fair economic matter which is investment activity in order to avoid a huge discrepancy between investors (rich people) and poor people who need financing support. So that there is no more the riches centralization because they have the same rights having a wealth and getting rid of poverty.

The implementation of BMT roles have been more efficient than other finance institutions because they have created a closed relationship with the customers. This closed relationship has minimizes some transactions cost. The main problem of BMT is relating to the collection of people finance due to people trust. For example, a support in designing a business plan, recording and bookkeeping community finance. But the problems have been solved since the establishment of Absindo, this association has a task to accredit LKMS BMT members, to educate them, to guide a business development to strengthen BMT capitals, to improve business relationship with other finance institutions either national or international ones. It has been indicated that the total of BMT has been increasing from year to year which is there are $3.000-4.000$ BMTs in Indonesia.

According to the aforemention descriptions, BMT financial sectors have been established due to lending finance capital to UMKM accordingly; real sectors have been performed due to educating the beginner UMKM, running the business to strengthen their finance capital obviously; religious sectors has been identifying that there is no more huge discrepancy between the finance capital owners(rich people) and poor people who need finance capital support thru the distribution of Zakat, Infaq and Shadaqoh (ZIS).

In connection with BPS data, the total of poor people had been decreasing since 2009 to September 2014 except in September 2013 due to the increasing price of main fundamental goods relating to the increasing price of petrol in June 2013. It is getting along 
with the increasing of BMT in Indonesia, it explains that BMT has a very important role in eliminating the poverty in Indonesia.

\section{CONCLUSION and SUGGESTIONS}

\section{A. Conclusion}

Some conclusions can be defined based on the aforemention research, as follows:

1. The role of BMT to develop financing sector has integrated two kinds of activities which is profit and non profit oriented. Social activity is a supporting one(Baitul Maal), and business activity is the main important one (Baitul Tamwil). Both of them are helping to provide people financing support.

2. BMT role in developing real sector education has identified that it has been educating and training the members regarding business procedures, working method or business management, consultation and supports, etc.

3, BMT role in religious improvement has explained that the development of BMT has succeeded to make more people invest their money. It has indicated that more people have paid their zakat, infaq and shadaqah. Furthermore, BMT has been able to erase bad image about the huge discrepancy or unfairness between the rich people and poor people.

5. BMT role in eliminating the poverty can be identified by looking back to the procedures and products they offer which is more flexible and do not burden the people, and it makes small or micro business people can get a financing support obviously. Moreover, BMT has not been only developing in the cities, but also in some villages.

\section{B. Suggestions} offered:

Based on the aforementioned conclusions, the following suggestions have been

1. In order to increase more the role of BMT in financing sector, BMTs should have to improve their services in connection with officers professionalism in serving the clients.

2. In order to support the development of real sectors, BMT should have to be able to improve the quality of human resources or officers that are dealing directly with the clients. It is very crucial to be done to get along with the knowledge and skills of the officers and the clients due to rapid development of technology and information

3. In order to improve the religious of the members, BMTs should have to be able to promote the benefit of their products accordingly. It is important to be done since all the products offered by BMT are relating to syariah, so that lot of new clients can be reached by giving them religious knowledge.

4. In order to eliminate the poverty in Indonesia, BMT can make better relationship with other syariah financing institutions. It is important to be done because BMT functions as an intermediary ones can make broader business networking and get more clients as wel.

\section{REFERENCES}

Abdul Majid Baihaki., A. Rasid Syaifuddin. 2000. Paradigma Baru Ekonomi Kerakyatan Sistem Syari'ah. Jakarta : PINBUK.

Amalia, Euis. 2009. Keadilan Distributif dalam Ekonomi Islam; Penguatan Peran LKM dan UKM di Indonesia, Edisi I. Jakarata : PT Rajawali Pers.

Antonio, Syafi'i. 2001. Bank Syari'ah : Dari Teori ke Praktek. Jakarta : Gema Insani.

Aries Muftie, 2014. Apex IMF is New Approach for Financial Inclusion and Community Development : One Village One BMT (IMF). Absindo, Indonesia International Conference on Islamic Finance : Surabaya. 
Arifin Zainul. 1999. Memahami Bank Syariah, Lingkup, Peluang, Tantangan dan Prospek. Jakarta : Alvabet.

Badan Pusat Statistik. 2015. Profil Kemiskinan di Indonesia September 2014. Berita Resmi Statistik : BPS. Jakarta.

Muttaqien, Dadan. 2010. Persepsi Nasabah terhadap Penerapan Prinsip Syari'ah dalam Operasional Lembaga Keuangan Mikro Syari'ah (Studi Kasus Nasabah BMT Haniva, Pleret, Bantul, Yogyakarta), Laporan Penelitian DPPM UII Yogyakarta.

Raharjo M. Dawan. 1999. Islam dan Transformasi Sosial-Ekonomi. Yogyakarta : Pustaka Pelajar.

Ridwan Muhammad. 2004. Manajemen Baitul Maal Wa Tamwil (BMT). Yogyakarta : UII Press.

Ritonga, Hamonangan. 2011. Pemantauan Kemiskinan untuk Program Penanggulangan Kemiskinan di Indonesia, Rabu 14 Desember 2011.

Safi'i. 2011. Ampih Kemiskinan; Model Kebijakan Penuntasan Kemiskinan dalam Perspektif Teori dan Praktik, Cetakan 1. Malang : Averroes Press.

Sudarsono Heri. 2005. Bank dan Lembaga Keuangan Syariah. Yogyakarta : Ekonisia.

Sumitro Warkum. 2004. Asas-Asas Perbankan Islam \& Lembaga-lembaga Terkait. Jakarta : PT. Raja Grafindo Persada.

Tambunan, Tulus, T.H. 2002. Usaha Kecil dan Menengah di Indonesia, Beberapa Isu Penting. Jakarta : Salemba Empat.

Tim Manajemen Program Pengorganisasian BMT. 2005. Pengembangan Ekonomi Kerakyatan Melalui Program BMT. Kerjasama UII Yogyakarta dan PKPEK, Yogyakarta, 14 Mei 2005.

Tim PINBUK. 1999. Pedoman Cara Mendirikan BMT. Surabaya : PINBUK Jawa Timur.

Yunus, Jamal Lulail. 2009. Manajemen Bank Syari'ah Mikro. Malang : UIN Malang Press.

Widyaningrum, Nurul. 2002. Modal Pembiayaan BMT dan Dampakanya bagi Pengusaha Kecil. Bandung : Yayasan Akatiga. 